\title{
Vernal keratoconjunctivitis: an update
}

\author{
Stefan De Smedt, ${ }^{1}$ Gerhild Wildner, ${ }^{2}$ Philippe Kestelyn ${ }^{3}$
}

${ }^{1}$ Ophthalmology Department, Kabgayi Hospital, Muhanga, Rwanda

${ }^{2}$ Section of Immunobiology, Department of Ophthalmology, Klinikum der Universität, Munich, Germany

${ }^{3}$ Ophthalmology Department, Ghent University Hospital, Ghent, Belgium

\section{Correspondence to} Dr Stefan De Smedt, Leopoldstraat 362800

Mechelen, Belgium; dr.stefan.desmedt@gmail.com

Received 23 April 2012 Revised 19 July 2012

Accepted 1 September 2012

Published Online First

4 October 2012
To cite: De Smedt $\mathrm{S}$, Wildner G, Kestelyn P. Br J Ophthalmol 2013, 97. 9-14.

\section{ABSTRACT}

Vernal keratoconjunctivitis (VKC) is a bilateral, usually seasonally recurrent, allergic inflammation of the conjunctiva, characterised by limbal gelatinous hypertrophy and/or upper tarsal giant conjunctival papillae. Although rare in temperate regions, it represents an important cause of hospital referral in many parts of Africa and Asia. Clinical and immunohistochemical studies suggest that lgE-dependent (type I allergic) and IgE-independent (type IV allergic) mechanisms are involved in the immunopathogenesis of VKC, in which various inflammatory cells, including different $\mathrm{T}$ cell subpopulations play an active role via a cascade of chemical mediators. Endocrine, genetic, neurogenic, environmental and socioeconomic risk factors have been identified. However, its aetiology and pathophysiology remain unclear. The clinical course of this disease is usually benign and self-limiting, but a minority of patients will face very debilitating and sight threatening complications. Topical corticosteroids are often used during flare-ups in combination with mast cell stabilizers as maintenance treatment for VKC. However this management is unsatisfactory in controlling severe cases and avoiding recurrences. Non-steroidal immune modulators such as ciclosporin A and tacrolimus are promising alternatives, but tolerance to these agents needs to be improved and production costs reduced. The purpose of this review is to give an update on its epidemiology, immunopathogenesis and management.

\section{EPIDEMIOLOGY}

Vernal keratoconjunctivitis (VKC) is a bilateral, chronic, external ocular inflammatory disorder, mainly affecting patients in their first or second decade ${ }^{1-3}$ Although it is a rare allergic disorder in temperate regions, in many parts of Africa, Latin America and Asia VKC represents an important cause for hospital attendance, ranging from 3\% to $6 \%$ of patients of all ages, rising to $33 \%$ and $90 \%$ in children and adolescents. ${ }^{2}{ }^{4-7}$ A population prevalence of $4 \%$ to $5 \%$ has been found among African children. ${ }^{3}{ }^{8}$ In large European and Asian case series boys appear to be affected more than girls, but this sex distribution is not found uniformly in Africa, and becomes less obvious with age. ${ }^{1-4}{ }^{8-11}$ Palpebral forms are more prevalent in Europe and the Americas, whereas mixed and limbal forms are more seen in Asia and Africa respectively, with some geographic variation. $.^{1-3} 68-$

14 In Europe and Asia VKC has a prominent seasonal variation in disease expression, but flare-ups during winter months can happen in a significant percentage of cases, leading to chronic, perennial disease after a few years. ${ }^{11} 14$ In Africa, however, VKC is less seasonal and occasionally continues until adulthood, explaining the substantial number of cases seen in clinics throughout the year. ${ }^{2} 5910$

\section{SYMPTOMS AND SIGNS}

Vernal keratoconjunctivitis is usually bilateral, although it can occasionally present unilaterally, at least initially. ${ }^{3} 15$ Its predominant symptom is intense ocular itching, followed by tearing, mucous stringy discharge, severe photophobia, blepharospasm and foreign body sensation.

It can present as purely palpebral or purely limbal disease, but a range of mixed appearances exist. ${ }^{10}$ The hallmark sign of palpebral VKC is papillary hyperplasia of the upper tarsal conjunctiva, ranging from papillae of $1 \mathrm{~mm}$ of diameter to typical giant or cobble stone papillae (figure 1). ${ }^{10}$ The dominating clinical sign in limbal VKC is infiltration of the limbal subconjunctival tissues forming nodules, sometimes accompanied by pannus of superficial neovascularisation of the peripheral cornea, making the limbus to appear thickened and opaque (figure 2). They often are topped by chalky white excrescences, known as HornerTrantas dots (figure 2). ${ }^{13}$ Increased spotty pigmentation of the interpalpebral exposed conjunctiva is common among patients from Africa and Asia, especially among very young children, but whether this sign is correlated to the disease activity is controversial. $^{8-1012}$

In tropical regions corneal complications develop in $7 \%$ to $50 \%$ of patients with VKC presenting to a hospital facility. ${ }^{1} 391016$ During exacerbations of palpebral VKC, punctate epithelial keratopathy may develop, leading to macroerosion and sight threatening shield ulcers (figure 3). ${ }^{13}{ }^{17}$ Generally, a shield ulcer is differentiated from an infective corneal ulcer by its transversely oval shape, and its location in the centre of the superior third of the cornea, but superinfection can occur. The base of a shield ulcer can be transparent or translucent, and can be filled with opaque white or yellow deposits, eventually forming an elevated plaque. ${ }^{17}$

Limbal disease can induce stem cell deficiency, that leads to compromised corneal surface, characterised by corneal vascularisation, chronic stromal inflammation, persistent epithelial defects and ingrowth of conjunctival epithelium onto the corneal surface. ${ }^{18}$ These central extension of limbal vegetations may affect vision (figure 4). ${ }^{6-13}$ Other corneal signs are subepithelial scarring, sterile stromal melt, pseudogerontoxon and keratoconus. ${ }^{1} 1920$

Although some signs and symptoms of VKC may be similar to other ocular allergic diseases, the presence of limbal and/or giant tarsal papillae differentiate VKC from seasonal allergic conjunctivitis (SAC) or perennial allergic conjunctivitis. ${ }^{21}$ VKC and atopic keratoconjunctivitis (AKC) are more severe forms of allergic eye disease. In contrast to VKC, AKC is more seen in older children and adults with an atopic history such as facial atopic dermatitis and does not regress quickly after adolescence. ${ }^{22}$ 


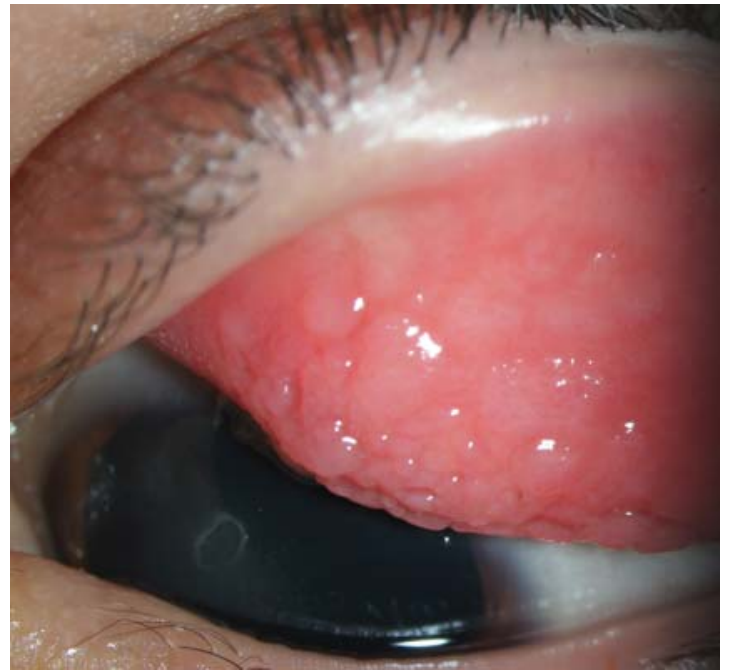

Figure 1 Giant papillary reaction of the tarsal conjunctiva causing a shield ulcer. This figure is only reproduced in colour in the online version.

Apart from the traditional distinction between limbal, palpebral and mixed types of VKC, various other classification systems, useful to appreciate the different degrees of severity of the disease and its corneal complications have been developed over time. $^{3} 5 \quad 10172023$ The average clinical presentation of VKC can differ significantly depending on geographic area and genetic background, so that there is no consensus on the definition of severity of disease in literature.

\section{HISTOPATHOLOGY}

Conjunctival biopsy specimens from patients with active VKC exhibit an intense influx of a variety of inflammatory cells, hyperplasia of the epithelium with numerous epithelial ingrowths, proliferation of new blood vessels and extensive deposition of extracellular matrix components (ECM). Substantia propria and epithelium are infiltrated by mast cells, eosinophils, basophils, plasma cells, monocytes/macrophages, dendritic cells, CD4 T lymphocytes, fibroblasts and B lymphocytes, organised as small lymphoid follicles. ${ }^{24}$ Inflammation of

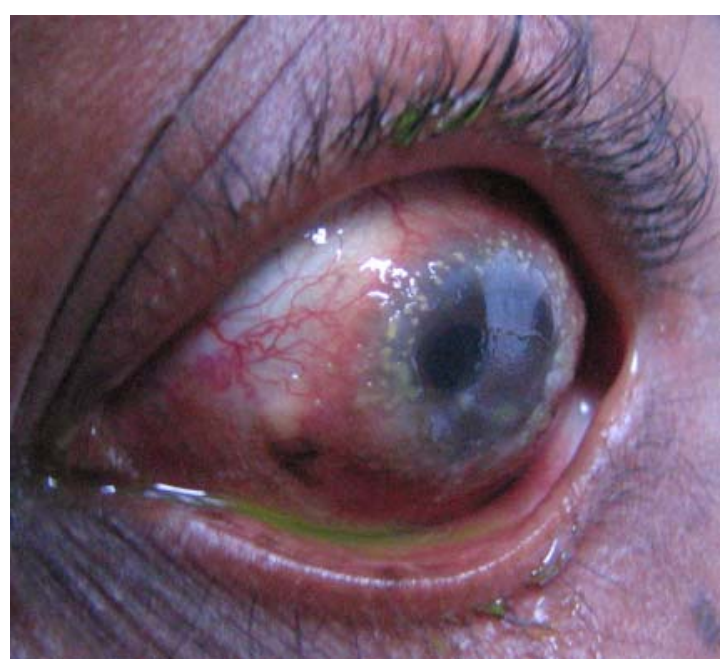

Figure 2 In this case of limbal vernal keratoconjunctivitis, the limbus appears thickened and opaque and topped by Horner-Trantas dots. This figure is only reproduced in colour in the online version.

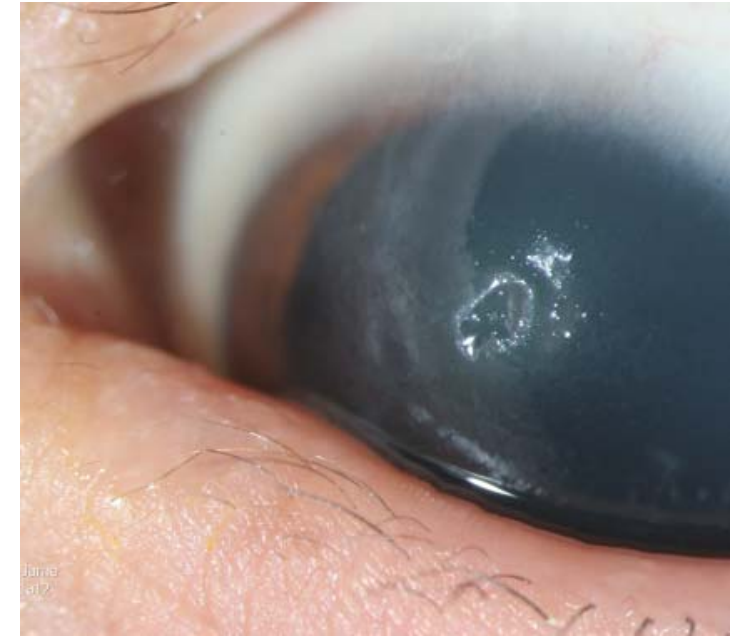

Figure 3 Corneal shield ulcer. This figure is only reproduced in colour in the online version.

the limbal palisades and the tarsal conjunctiva produces nodules, due to the firm attachments of the conjunctiva to limbus and tarsus respectively. Giant papillae are characterised by squamous epithelial hyperplasia and dense fibrous tissue, harbouring the described population of inflammatory cells. ${ }^{25}$ Limbal VKC is histologically differentiated from the palpebral form by the enormous epithelial overgrowth with solid downward extensions of epithelial plugs in the limbal tissue. It has not yet been fully explained why in tropical regions changes in vernal conjunctivitis tend to localise at the limbus rather than in the tarsal palpebral conjunctiva, as in temperate climates. Nevertheless, there is a more prominent B lymphocyte clustering at the limbus in patients with VKC from tropical countries, ${ }^{16}$ and in dark skinned people the limbus is richer on mast cells and melanocytes. ${ }^{26}$

\section{DIAGNOSIS AND ASSOCIATION WITH OTHER ATOPIC CONDITIONS}

Diagnosis is mainly based on the typical clinical VKC signs. So far only a few laboratory tests are used to confirm the disease.

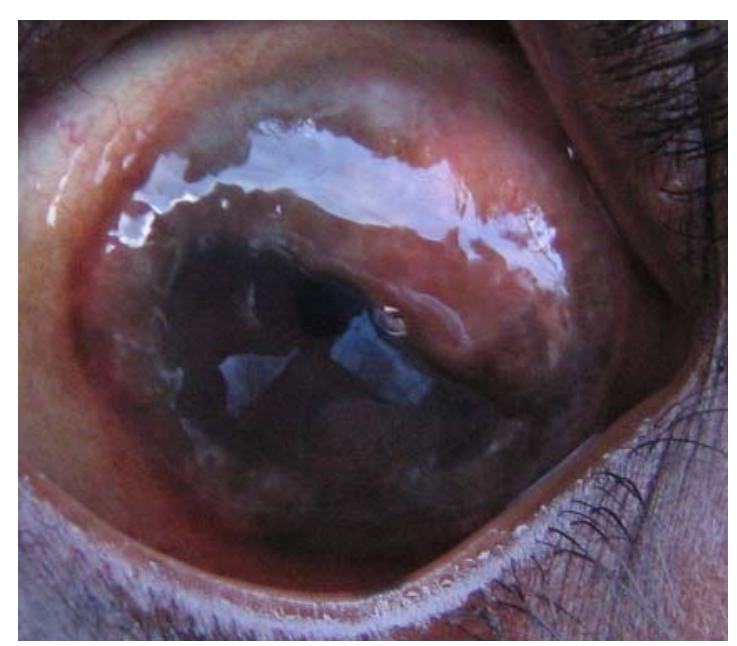

Figure 4 Central extension of limbal vegetations in limbal vernal keratoconjunctivitis. This figure is only reproduced in colour in the online version. 
The eosinophils usually found in conjunctival scrapings of patients with VKC support the diagnosis, but their absence does not exclude it. ${ }^{11}{ }^{13}{ }^{27}$ Total and specific immunoglobulin $\mathrm{E}$ (IgE) determination in tears and serum and skin prick tests can provide additional evidence, but there is a high variability in IgE levels, and skin tests may not always be positive among VKC cases, especially in Africa. ${ }^{8} 1113$ Limbal and palpebral forms do not differ in IgE levels in serum or tears. ${ }^{13}$

Recently, confocal microscopy has been used to quantify in a non-invasive manner the morphological characteristics of the conjunctiva and limbus in VKC. ${ }^{28}$

A higher incidence of associated atopic conditions such as asthma, rhinitis and eczema has been reported among patients with VKC in up to $41.5 \%$ of cases, although this was not found everywhere. ${ }^{1} \quad 3 \quad 11 \quad 29-31$ Especially in Africa the majority of studies reported only a small percentage of patients with these other atopic diseases. ${ }^{4-10}$

\section{IMMUNOPATHOGENESIS}

Many clinical and laboratory findings support the presence of a type I (IgE-dependent) immediate hypersensitivity reaction in VKC. ${ }^{32-35}$ B lymphocytes from the lymphoid follicle of the conjunctiva locally produce $\operatorname{IgE} .^{36}$ Mast cell degranulation results in the release of a range of mediators such as histamine, leading to the classical allergic reactions of vasodilatation, oedema, hyperaemia, smooth muscle contraction and the recruitment of other inflammatory cells.

The important role of the eosinophil in the pathogenesis of ocular allergy is suggested by the consistent presence of this cell type in conjunctival biopsy tissues affected by ocular allergy and by eosinophilic cationic protein levels in tears. ${ }^{37} 38$ Activated eosinophils elicit ocular surface inflammation by their soluble mediators and adhesion molecules and the inflammation can even lead to corneal epithelial breakdown. ${ }^{39}$

The fact that there is no strict requirement for allergenspecific sensitisation to result in this eosinophilic response, and the conflicting results in the literature concerning the association between VKC and atopy suggest that IgE-independent mechanisms are also involved. ${ }^{1} 111329-314041$ In this pathway it is postulated that antigen-presenting cells induce an influx of eosinophils from the blood vessels into the conjunctival tissue by chemokines. ${ }^{40}$ These chemokines can also activate mast cells independently of IgE ('pseudoallergic reaction') and attract T lymphocytes. ${ }^{42}$

There is also growing evidence for the involvement of a CD4 T helper 2 (Th2)-driven type IV (delayed or cell-mediated) hypersensitivity reaction as well. ${ }^{3} 294344$ In order to adhere to endothelial and antigen-presenting cells and become active, $\mathrm{T}$ lymphocytes need cell adhesion molecules, which are increasingly expressed in VKC. Once activated, these Th2 lymphocytes play a role in recruitment and activation of mast cells and eosinophils, ${ }^{45-48}$ and in B cell switching to the production of IgE. No differences in the percentage of Th2 lymphocytes were found between patients with tarsal or limbal affection. ${ }^{46}$ Recently, it has been suggested that other T cells (CD4 Th1 cells and CD8 T cells) may play a role as well. ${ }^{48-5152}$

Apart from acting as simple physical barrier to the entrance of foreign invaders, ocular surface epithelium is actively involved in the initiation and continuation of the allergic inflammatory process. The epithelium is stimulated by inflammatory molecules, such as histamine, to express intercellular adhesion molecules (ICAM-1) and to secrete inflammatory cytokines and chemokines. Chemokine receptor CXCR3 is abundantly expressed on $\mathrm{T}$ lymphocytes in VKC conjunctiva, suggesting its involvement in the regulation of lymphocyte recruitment. ${ }^{53}$ Furthermore, the conjunctival hyperplasia is modulated by growth factors and conjunctival epithelial cells interact with activated T cells via CD40 adhesion molecules in vitro. ${ }^{54} 55$

Mononuclear cells and eosinophils affect fibroblast functions via histamine, cytokines, integrin receptors and a range of growth factors. ${ }^{56}$ As part of the remodelling of the conjunctiva in VKC, extensive deposition of ECM happens in the substantia propria, including collagen types I, III, IV, V and VII, tenascin and laminin. ${ }^{57}$ Laminin and tenascin facilitate the transmigration of inflammatory cells into the conjunctiva via their adhesive properties and induce matrix metalloproteinases (MMPs) such as gelatinase $\mathrm{B}$, that disrupt the integrity of the ECM, allowing invasion of inflammatory cells and contributing to tissue remodelling. ${ }^{58}{ }^{59}$ MMP enzymes are inactivated by tissue inhibitors of MMPs (TIMP-1). Increased levels and activity of MMP and an imbalance between MMPs and TIMP may be involved in the pathogenesis of VKC. ${ }^{60}$

\section{RISK FACTORS}

An endocrine risk factor has been suggested by the following clinical and immunohistochemical findings; (1) sexual disparity in VKC prevalence, ${ }^{8}{ }^{11}$ (2) the role of sex hormones in other immunological diseases, ${ }^{61}$ (3) overexpression of oestrogen and progesterone receptors by conjunctival eosinophils and altered neuroreceptor expression in conjunctival epithelium in $\mathrm{VKC}^{54}$ and (4) growth factors, neuropeptides such as substance P and prostaglandins detected in high amounts in serum and tears in VKC. ${ }^{14} 6263$

The difference in prevalence of limbal and palpebral VKC observed in different races in the same study region and the identification of disease susceptibility genes for ocular allergy via linkage analysis support the important role of a genetic risk factor. ${ }^{9} 1364$

Exposure to ultraviolet light, diesel fumes or smoking might also influence signs and symptoms of allergic conjunctivitis. ${ }^{9} 16$ Staphylococcal colonisation of the lid margins has also been suggested to influence the VKC pathogenesis. ${ }^{65}$

Although coexistent trachoma had been proposed to play a role via type IV hypersensitivity reaction on the intraepithelial chlamydial inclusions in the conjunctival epithelium, no correlation was found between the prevalence of chlamydial infection and the prevalence of VKC. ${ }^{13} 1066$

The influence of helminth infestation on the pathogenesis is controversial. Some clinical studies reported a reduction in allergic conjunctivitis symptoms following antiparasitic treatment, while laboratory studies observed a reduction in allergic conjunctivitis parameters in Ascaris and Cholera toxin B treated mouse models. ${ }^{3}$ 67-69 A nested population-based case control study in Rwandan primary schools did not find any association between VKC and current intestinal parasitic load, but identified higher economic status as a risk for VKC. ${ }^{8}$ This effect appears not to act through differences in parasitic intestinal load.

\section{TREATMENT}

\section{Topical medication}

Because the exact immunopathogenesis of VKC remains unknown, the same topical antiallergic agents are used as for other forms of allergic conjunctivitis.

Topical antihistamines, such as levocabastine and emedastine alleviate ocular allergy quickly by binding to histamine receptors but are only effective in mild cases. ${ }^{45} 70$ Mast cell stabilisers such as cromolyn sodium, nedocromil sodium, lodoxamide and pemirolast interfere with the release of mast cell mediators by 
blocking calcium transport across the mast cell membrane requiring prophylactic treatment or a loading period. ${ }^{71}$ Although mast cell stabilisers are unanimously effective in studies in Europe and North America, results from the Middle East and Africa have not consistently shown a benefit. $^{3} 9163171-73$

Dual action agents such as olopatadine and ketotifen combine the best of both worlds by their immediate histamine receptor antagonism, coupled with the long-term disease-modifying effect of mast cell stabilisation. ${ }^{74}$

Non-steroidal anti-inflammatory drug (NSAID) topical agents reduce ocular inflammatory signs by inhibiting cyclooxygenase and have a beneficial effect on the course of VKC reducing the local steroid needs. ${ }^{20}{ }^{75-77}$ Careful follow-up is needed, since corneal melting has been reported after instillation of several types of topical NSAID. ${ }^{78}$ However, in severe VKC the above mentioned agents often appear inadequate, making the use of corticosteroid drops inevitable. Topical corticosteroids are the most effective treatment for moderate to severe forms of $\mathrm{VKC}$ because of their broad and early interference with the inflammatory cascade. ${ }^{3} 2079$ Their use should be strictly limited and carefully monitored because of the known complications of long-term steroid use (glaucoma, cataract and secondary ocular infections). ${ }^{1} 3101137$ Loteprednol, a smart ester-corticosteroid with an better safety profile has been effective in SAC, but its efficacy in VKC is unknown. ${ }^{80}$

Ciclosporin A (CsA) is an established option for the management of VKC. It is a calcineurin inhibitor that abolishes $\mathrm{T}$ cell proliferation via inhibition of CD4 T cell receptor signal transduction and down regulation of interleukin (IL)-2 receptor expression. ${ }^{81}$ It also inhibits apoptosis, eosinophil and mast cell activation and the release of IL-2, IL-1 $\beta$ and IL-5, which are important mediators of allergic inflammation. ${ }^{82}$ Double-masked placebo-controlled studies performed in Europe and Asia report a beneficial effect of topical CsA $2 \%$ in the treatment of VKC with an aggregate reduction in scores for symptoms and signs ranging from $45 \%$ to $55 \%$ after 2 weeks. ${ }^{83} 84$ In an open trial topical CsA $1 \%$ has been suggested to be the minimal effective concentration in severe VKC. ${ }^{85}$ Studies on off-label use of topical CsA 0.05\% (Restasis; Allergan, Irvine, California, USA) have reported conflicting evidence on its beneficial effects in severe allergic conjunctivitis. ${ }^{86-88}$ In a double-masked, randomised controlled clinical trial (RCT) no difference in efficacy between CsA $2 \%$ and dexamethasone $0.1 \%$ was found in the treatment of limbal VKC in Africa, but CsA was less well tolerated. ${ }^{89}$ Using a lower dose, an Italian trial demonstrated an inferior efficacy of CsA $(0.1 \%)$ compared with dexamethasone $0.15 \% .{ }^{90}$ Chronic use of topical CsA $0.05 \%$ has been shown to be effective in preventing seasonal recurrences of VKC. ${ }^{90}$

Tacrolimus, another immunomodulator, has a similar mechanism as CsA but is more potent. ${ }^{91}$ Case series and placebocontrolled RCT have shown a beneficial effect of tacrolimus ointment $(0.1 \%$ to $0.2 \%)$ and drops $(0.005 \%$ and $0.1 \%)$ in severe VKC. ${ }^{92-94}$ However, it makes patients more susceptible for opportunistic infections and herpes simplex keratitis. ${ }^{94}$

Although CsA and tacrolimus might be powerful alternatives for corticosteroids in the management of VKC, a higher cost price limit their wide spread use in the developing world.

Monoclonal antibodies directed against IgE antibody, adhesion molecules and chemokines receptors may interfere with the immunopathogenesis of VKC and represent new therapeutic modalities. $^{249596}$

Recently, an algorithm approach to the management of VKC has been proposed in palpebral VKC. ${ }^{21}$ This clinical grading system is based on disease severity, expressed in terms of symptom/sign intensity and frequency and the presence of corneal involvement. It may help clinicians and researchers to reach agreement on which therapeutic option is appropriate for which disease activity.

\section{Oral medication}

Montelukast (a leukotriene antagonist) and aspirin tablets have been reported as treatment options. ${ }^{97} 98$ Oral ciclosporin $(3-5 \mathrm{mg} / \mathrm{kg} /$ day) has been successfully used in refractory severe VKC. ${ }^{99}$ The use of oral steroids and antihistamine is limited by their systemic side effects. ${ }^{3} 209798100$

\section{Periocular injections and surgery}

Supratarsal injection of corticosteroids is very effective for temporary suppression of severe inflammation associated with VKC, but it is difficult to administer to small children without sedation, and recurrence has been reported in the majority of patients within 6 months. ${ }^{101}$

A surgical approach has been tried in severe and complicated cases. Early surgical scraping dramatically improve epithelial resurfacing in corneal shield ulcers. ${ }^{17} 37$ Corneal scars can be removed either surgically or by excimer laser phototherapeutic superficial keratectomy, and penetrating keratoplasty has a good clinical outcome for keratoconus in VKC. ${ }^{17} 102$

Persistent corneal epithelial defects can be treated by amniotic membrane transplantation and limbal epithelial cell transplantation. ${ }^{103}{ }^{104} \mathrm{~A}$ Boston keratoprosthesis has successfully been implanted for severe blinding VKC. ${ }^{105}$

Treatment of tarsal or limbal papillae in severe VKC by cryotherapy or laser have been reported, but may only have a transient response and destruction of the limbus may exacerbate corneal stem cell failure. ${ }^{1} 5106$

\section{PROGNOSIS}

Generally VKC is a benign and self-limiting condition with spontaneous resolution after puberty without any further symptoms or visual complication, but therapeutic action may be necessary beyond this age to control the course of the disease. $^{5} 10^{11}$ In large hospital-based case series VKC has the potential to induce serious visual changes in $6 \%$ to $55 \%$ of patients depending on the regions of origin. ${ }^{1} 91137107$ This is due to corneal complications and unsupervised corticosteroid use. $^{116}$ A chronic disease course has been found to increase the odds for complications and the development of keratoconus. ${ }^{16} 11$ Signs indicating deterioration were the size of cobble stones, the presence of Trantas dots and the number of eosinophils on conjunctival scrapings. 31137

\section{CONCLUSIONS}

VKC is a bilateral, allergic inflammation of the conjunctiva, affecting predominantly boys in warm climates. The distribution of the main clinical hallmarks, upper tarsal giant conjunctival papillae and gelatinous limbal hypertrophy, varies considerably with different climatic conditions and races. Clinical and immunohistochemical studies suggest that IgE-dependent and IgE-independent mechanisms are both involved in its immunopathogenesis, in which various inflammatory cells, including different $\mathrm{T}$ cell subpopulations play an active role. Although endocrine, genetic, neurogenic, environmental and socioeconomic factors have been identified, its aetiology remains unknown. Despite new insights in the mechanisms of ocular allergy, topical steroidal and non-steroidal immune modulators 
remain the standard treatment but are often unsatisfactory in controlling severe cases and avoiding regular flare-ups.

Contributors SDS and PK substantially contributed to conception and design and interpretation of data; drafting the article or revising it critically for important intellectual content; and approved the final version to be published. GW contributed to the design, revision and approval of the immunopathogenesis section of the paper.

\section{Competing interests None.}

Provenance and peer review Not commissioned; externally peer reviewed.

\section{REFERENCES}

1 Khan MD, Kundi N, Saeed N, et al. A study of 530 cases of vernal conjunctivitis from the North West Frontier Province of Pakistan. Pak J Ophthalmol 1986:2:111-14

2 Chenge B, Makumyamviri AM, Kaimbo wa Kaimbo D. La limbo-conjonctivite endemique des tropiques à Lubumbashi, Republique Démocratique du Congo. Bull Soc belge Ophtalmol 2003;290:9-16.

3 Resnikoff S, Cornand G, Filliard G, et al. Limbal vernal conjunctivitis in the tropics, Rev Int Trachome 1988;3-4:53-71.

4 McMoli T, Assonganyi T. Limbal vernal kerato-conjunctivitis in Yaounde, Cameroon. A clinico-immunology study. Rev Int Trach Pathol Ocul Trop Subtrop Sante Publique 1991;68:157-70.

5 Diallo J-S. La limbo-conjonctivite endémique des tropiques. Rev Int Trachome 1976;3-4:71-9.

6 Dantas PEC, Alves MR, Nishiwaki-Dantas MC. Topographic corneal changes in patients with vernal keratoconjunctivitis. Arq Bras Oftalmol 2005;68:593-98.

7 Uchio E, Kimura R, Migita H, et al. Demographic aspects of allergic ocular diseases and evaluation of new criteria for clinical assessment of ocular allergy. Graefes Arch Clin Exp Ophthalmol 2008:291-96.

8 De Smedt S, Nkurikiye J, Fonteyne Y, et al. Vernal keratoconjunctivitis in school children in Rwanda and its association with socio-economic status: a population-based survey. Am J Trop Med Hyg 2011;85:711-17.

9 Dahan E, Appel R. Vernal keratoconjunctivitis in the black child and its response to therapy. Br J Ophthalmol 1983:67:688-92.

10 Sandford-Smith J. Vernal eye disease in Northern Nigeria. Trop Geogr Med 1979:31:321-28

11 Bonini S, Bonini S, Lambiase A, et al. Vernal keratoconjunctivitis revisited. A case series of 195 patients with long-term followup. Ophthalmology 2000;107:1157-63

12 Rao SK, Meenakshi S, Srinivasan B, et al. Perilimbal Bulbar Conjunctival Pigmentation in Vernal Conjunctivitis Prospective Evaluation of a New Clinical Sign in an Indian Population. Cornea 2004;23:356-59.

13 Tuft SJ, Dart JKG, Kemeny M. Limbal vernal keratoconjunctivitis: clinical characteristics and immunoglobulin E expression compared with palpebral vernal. Eye 1989;3:420-27.

14 Pucci N, Novembre E, Lombardi E, et al. Long Eyelashes in a Case Series of 93 Children With Vernal Keratoconjunctivitis. Pediatrics 2005;115:86-91.

15 Awwad ST, Najjar DM, Aouad A, et al. Vernal keratoconjunctivitis presenting unilaterally. J Pediatr Ophthalmol Strabismus 2006:43:179-80.

16 Tuft SJ, Cree IA, Woods M, et al. Limbal vernal keratoconjunctivitis in the tropics. Ophthalmology 1998;105:1489-93.

17 Cameron JA. Shield ulcers and plaques of the cornea in vernal keratoconjunctivitis. Ophthalmology 1995;102:985-93.

18 Sangwan VS, Jain V, Vemuganti GK, et al. Vernal keratoconjunctivitis with limbal stem cell deficiency. Cornea 2011;30:491-96.

19 Totan Y, Hepsen IF, Cekiç O, et al. Incidence of keratoconus in subjects with vernal keratoconjunctivitis: a videokeratographic study. Ophthalmology 2001;108:824-27.

20 Buckley RJ. Vernal keratopathy and its management. Trans Ophthalmic Soc UK 1981;101:234-38.

21 Bonini S, Sacchetti M, Mantelli F, et al. Clinical grading of vernal keratoconjunctivitis. Curr Opin Allergy Clin Immunol 2007;7:436-41.

22 Tuft SJ, Kemeny M, Dart J, et al. Clinical features of atopic keratoconjunctivitis. Ophthalmology 1991;98:150-58.

23 Akpek EK, Hasiripi H, Christen WG, et al. A randomised trial of low-dose, topical mitomycine-C in the treatment of severe vernal keratoconjunctivitis. Ophthalmology 2000;107:263-69.

24 Abu El-Asrar A, Geboes K, Al-Kharashi S, et al. Adhesion molecules in vernal keratoconjunctivitis. Br J Ophthalmol 1997;81:1099-106

25 Takakusaki I. Fine structure of the human palpebral conjunctiva with special reference to the pathological changes in vernal conjunctivitis. Arch Histol Jap 1969:30:247-82.

26 Soukiasian S, Rice B, Foster C. The T cell receptor in normal and inflamed human conjunctiva. Invest Ophthalmol Vis Sci 1992:33:453-59.
27 Bonini S, Lambiase A, Sgrulletta R, et al. Allergic chronic inflammation of the ocular surface in vernal keratoconjunctivitis. Curr Opin Allergy Clin Immunol 2003:3:381-87.

28 Le Q, Hong J, Zhu W, et al. In vivo laser scanning confocal microscopy of verna keratoconjunctivitis. Clinical and Experimental Ophthalmology 2011;39:53-60.

29 Frankland A, Easty D. Vernal keratoconjunctivitis- an atopic disease. Trans Ophthal Soc UK 1971;91:479-82.

30 Neumann E, Gutmann M, Blumankrantz N, et al. A review of four hundred cases of vernal keratoconjunctivitis. Am J Ophthalmol 1959;47:166-72.

31 El Hennawi M. Clinical trial with $2 \%$ sodium cromoglycate in vernal keratoconjunctivitis. Br J Ophthalmol 1980;64:483-86.

32 Ballow M, Mendelson L. Specific immunoglobulin E antibodies in tear secretions of patients with vernal conjunctivitis. J Allergy Clin Immunol 1980;66:112-18.

33 Allansmith M, Hann G, Simon M. Tissue tear and serum lgE concentrations in vernal conjunctivitis. Am J Ophthalmol 1976;81:506-11.

34 Aalders-Deenstra V, Kok P, Bruynzeel P. Measurement of total IgE antibody levels in lacrimal fluid of patients suffering from atopic and non-atopic eye disorders. Evidence for local IgE production in atopic eye disorders? Br I Ophthalmol 1985:69:380-84.

35 Samra Z, Zavaro A, Barishak Y, et al. Vernal keratoconjunctivitis: the significance of immuneglobuline E levels in tears and serum. Int Archs Allergy Appl Immunol 1984;74:158-64.

36 Abu El-Asrar A, Fatani RA, Missotten L, et al. Expression of CD23/CD21 and CD40/CD40 ligand in vernal keratoconjunctivitis. Eye 2001;15:217-24.

37 Tabbara KF. Ocular complications of vernal keratoconjunctivitis. Can J Ophthalmol 1999:34:88-92.

38 Leonardi A, Borhesan F, Faggian D, et al. Eosinophil cationic protein in tears of normal subjects and patients affected by vernal keratoconjunctivitis. Allergy 1995:50:610-13.

39 Trocme SD, Leiferman KM, George T, et al. Neutrophil and eosinophil participation in atopic and vernal keratoconjunctivitis. Curr Eye Res 2003;26:319-25.

40 Pucci N, Novembre E, Lombardi E, et al. Atopy and serum eosinophil cationic protein in 110 white children with vernal keratoconjunctivitis: differences between tarsal and limbal forms. Clin Exp Allergy 2003:33:325-30.

41 Allansmith M. Vernal conjunctivitis. In: Duane TD, ed. Clinical Ophthalmology. vol 4. Chap 9. New York: Harper and Row, 1980.

42 Abu El-Asrar A, Struyf S, Al-Kharashi S, et al. Expression of T lymphocyte chemoattractants and activation markers in vernal keratoconjunctivitis. $\mathrm{Br} \mathrm{J}$ Ophthalmol 2002;86:1175-80.

43 Bacon A, Tuft S, Metz D. The origin of keratopathy in chronic allergic eye disease: a histopathological study. Eye 1993;7:21-5.

44 Bonini S, Bonini S. IgE and non-IgE mechanisms in ocular allergy. Ann Allergy 1993:71:296-99.

45 Ono SJ, Abelson MB. Allergic conjunctivitis: update on pathophysiology and prospects for future treatment. J Allergy Clin Immunol 2005;115:118-22.

46 Leonardi A, DeFranchis G, Zancanaro F, et al. Identification of local Th2 and Th0 lymphocytes in vernal conjunctivitis by cytokine flow cytometry. Invest Ophthalmol Vis Sci 1999;40:3036-40.

47 Abu El-Asrar AM, al-Kharashi S, al-Mansouri S, et al. Langerhans' cells in vernal keratoconjunctivitis express the costimulatory molecule B7-2 (CD86), but not B71 (CD80). Eye 2001;15:648-54.

48 Leonardi A, Fregona IA, Plebani M, et al. Th1- and Th2-type cytokines in chronic ocular allergy. Graefes Arch Clin Exp Ophthalmol 2006;244:1240-45.

49 Sumi T, Fukushima A, Fukuda K, et al. Thymus-derived CD4+ CD25+ T cells suppress the development of murine allergic conjunctivitis. Int Arch Allergy Immunol 2007:143:276-81.

50 Sgrulletta R, Bonini S, Lambiase A, et al. Allergy and infections: long-term improvement of vernal keratoconjunctivitis following viral conjunctivitis. Eur $J$ Ophthalmol 2006;16:470-3.

51 Stern ME, Siemasko KF, Niederkorn JY. The Th1/Th2 paradigma in ocular allergy. Curr Opin Allergy Clin Immunol 2005;5:446-50.

52 Fukushima A, Yamaguchi T, Fukuda K, et al. CD8+ T cells play disparate roles in the induction and the effector phases of murine experimental allergic conjunctivitis. Microbiol Immunol 2006;50:719-28.

53 Abu El-Asrar AM, Struyf S, Van Damme J, et al. Role of chemokines in vernal keratoconjunctivitis. Int Ophthalmol Clin 2003;43:33-9.

54 Calonge M, Enriquez de Salamanca A. The role of the conjunctival epithelium in ocular allergy. Curr Opin Allergy Clin Immunol 2005;5:441-45.

55 Abu El-Asrar AM, Al-Mansouri S, Tabbara KF, et al. Immunopathogenesis of conjunctival remodelling in vernal keratoconjunctivitis. Eye 2006:71-9.

56 Abu El-Asrar AM, Al-Mansouri S, Tabbara KF, et al. Immunopathogenesis of conjunctival remodelling in vernal keratoconjunctivitis. Eye 2006;20:71-9.

57 Abu El-Asrar AM, Geboes K, Al-Kharashi S, et al. An immunohistochemical study of collagens in trachoma and vernal keratoconjunctivitis. Eye 1998;12:1001-06

58 Abu El-Asrar A, Meersschaert A, Al-Kharashi S, et al. Immunohistochemical evaluation of conjunctival remodelling in vernal keratoconjunctivitis. Eye 2003:17:767-71. 
59 Abu El-Asrar AM, Van Aelst I, Al-Mansouri S, et al. Gelatinase B in vernal keratoconjunctivitis. Arch Ophthalmol 2001;119:1505-11.

60 Leonardi A, Brun P, Abatangelo G, et al. Tear Levels and Activity of Matrix Metalloproteinase (MMP)-1 and MMP-9 in Vernal Keratoconjunctivitis. Invest Ophthalmol Vis Sci 2003:3052-58.

61 Seamon V, Vellala K, Zylberberg C, et al. Sex hormone regulation of tear lipocalin in the rabbit lacrimal gland. Exp Eye Res 2008;87:184-90.

62 Fujishima H, Takeyama M, Takeuchi T, et al. Elevated levels of substance $P$ in tears of patients with allergic conjunctivitis and vernal keratoconjunctivitis. Clin Exp Allergy 1997;27:372-78.

63 Sacchetti M, Micera A, Lambiase A, et al. Tear levels of neuropeptides increase after specific allergen challenge in allergic conjunctivitis. Mol Vis 2011;17:47-52.

64 Ono S, Nakamura T, Ohbayashi M, et al. Expression profiling: opportunities and pitfalls and impact on the study and management of allergic diseases. J Allergy Clin Immunol 2003;112:1050-56.

65 Tuft SJ, Ramakrishnan M, Seal DV, et al. Role of staphylococcus aureus in chronic allergic conjunctivitis. Ophthalmology 1992;99:180-84.

66 Friedlaender $\mathrm{MH}$, Cameron J. Vernal keratoconjunctivitis and trachoma. Int Ophthalmol 1988;12:47-51.

67 McConchie BW, Norris HH, Bundoc VG, et al. Ascaris suum-derived products suppress mucosal allergic inflammation in an interleukin-10-independent manner via interference with dendritic cell function. Infect Immun 2006;74:6632-41.

68 Schopf L, Luccioli S, Bundoc V, et al. Differential modulation of allergic eye disease by chronic and acute ascaris infection. Invest Ophthalmol Vis Sci 2005:46:2772-80.

69 Saito K, Shoji J, Inada N, et al. Immunosuppressive effect of cholera toxin B on allergic conjunctivitis model in the guinea pig. Jpn J Ophthalmol 2000;44:189-90.

70 Bielory L, Ghafoor S. Histamine receptors and the conjunctiva. Curr Opin Allergy Clin Immunol 2005;5:437-40.

71 Easty D, Rice N, Jones B. Disodium cromoglycate (Intal) in the treatment of vernal-kerato-conjunctivitis. Trans Ophthal Soc UK 1971;91:491-99.

72 Sayegh F, Samerra E, Khateeb M. Clinical trial of topical DSG in vernal keratoconjunctivitis. Ophthalmologica 1978;177:208-13.

73 Foster SC. Evaluation of topical cromolyn sodium in the treatment of vernal keratoconjunctivitis. Ophthalmology 1988;95:194-201.

74 Yanni J, Stephens D, Miller S, et al. The in vitro and in vivo ocular pharmacology of olopatadine (AL-4943A), an effective anti-allergic/antihistaminic agent. J Ocul Pharmacol Ther 1996;12:389-400.

75 Duzman E, Warman A, Warman R. Efficacy and safety of topical oxymetazoline in treating allergic and environmental conjunctivitis. Ann Ophtalmol 1986;1:28-31.

76 Sugar J, Nysberg M, Bernstein J, et al. Imipramine inhibition of ragweed allergic conjunctivitis. Invest Ophthalmol Vis Sci 1984;25:217-18.

77 Syrbopoulos S, Gilbert D, Easty D. Double- blind comparison of a steroid (prednisolone) and non-steroid (tolmetine) in vernal keratoconjunctivitis. Cornea 1986:5:35-9.

78 Asai T, Nakagami T, Mochizuki M, et al. Three cases of corneal melting after instillation of a new nonsteroidal anti-inflammatory drug. Cornea 2006;25:224-27

79 Bielory BP, Perez VL, Bielory L. Treatment of seasonal allergic conjunctivitis with ophthalmic corticosteroids: in search of the perfect ocular corticosteroids in the treatment of allergic conjunctivitis. Curr Opin Allergy Clin Immunol 2010;10:469-77.

80 Dell S, Lowry G, Northcutt J, et al. A randomized, double-masked, placebo-controlled parallel study of $0.2 \%$ loteprednol etabonate in patients with seasonal allergic conjunctivitis. J Allergy Clin Immunol 1998;102:251-55.

81 Nussenblat R, Palestine A. Cyclosporine: immunology, pharmacology and therapeutic uses. Surv Ophthalmol 1986;31:159-69.

82 Whitcup SM, Chan C-C, Luyo DA, et al. Topical cyclosporine inhibits mast cell-mediated conjunctivitis. Invest Ophthalmol Vis Sci 1996;37:2686-93.

83 Pucci N, Novembre E, Cianferoni A, et al. Efficacy and safety of cyclosporine eyedrops in vernal keratoconjunctivitis. Ann Allergy Asthma Immunol 2002;89:298-303.
84 Kiliç A, Gürler B. Topical 2\% cyclosporine A in preservative-free artificial tears for the treatment of vernal keratoconjunctivitis. Can J Ophthalmol 2006;41:693-98.

85 Spadavecchia L, Fanelli P, Tesse R, et al. Efficacy of $1.25 \%$ and $1 \%$ topical cyclosporine in the treatment of severe vernal keratoconjunctivitis in childhood. Pediatr Allergy Immunol 2006;17:527-32.

86 Ozcan AA, Ersoz TR, Dulger E. Management of severe allergic conjunctivitis with topical cyclosporine 0.05\% eye drops. Cornea 2007;26:1035-38.

87 Akpek EK, Dart JK, Watson S, et al. A Randomized Trial of Topical Cyclosporin 0.05\% in Topical Steroid-Resistant Atopic Keratoconjunctivitis. Ophthalmology 2004;111:476-82.

88 Daniell M, Constantinou M, Vu HT, et al. Randomised controlled trial of topical ciclosporin A in steroid dependent allergic conjunctivitis. Br J Ophthalmol 2006;90:461-64.

89 De Smedt S, Nkurikiye J, Fonteyne Y, et al. Topical ciclosporin in the treatment of vernal keratoconjunctivitis in Rwanda, Central Africa: a prospective, randomised, double-masked, controlled clinical trial. Br J Ophthalmol 2012;96:323-28.

90 Lambiase A, Leonardi A, Sacchetti M, et al. Topical cyclosporine prevents seasonal recurrences of vernal keratoconjunctivitis in a randomized, double-masked, controlled 2-year study. J Allergy Clin Immunol 2011;128:896-97.

91 Vichyanond P, Tantimongkolsuk C, Dumrongkigchaiporn P, et al. Vernal keratoconjunctivitis: result of a novel therapy with $0.1 \%$ topical ophthalmic FK-506 ointment. J Allergy Clin Immunol 2004;113:355-58.

92 Tam $P$, Young A, Cheng $L$, et al. Topical tacrolimus $0.03 \%$ monotherapy for vernal keratoconjunctivitis- case series. Br J Ophthalmol 2010;94:1405-6.

93 Kheirkhah A, Zavareh M, Farzbod F, et al. Topical 0.005\% tacrolimus eye drop for refractory vernal keratoconjunctivitis. Eye 2011;25:872-80.

94 Ohashi Y, Ebihara N, Fujishima $\mathrm{H}$, et al. A randomized, placebo-controlled clinical trial of tacrolimus ophthalmic suspension $0.1 \%$ in severe allergic conjunctivitis. J Ocul Pharmacol Ther 2010;26:165-74.

95 Sánchez J, Cardona R. Omalizumab. An option in vernal keratoconjunctivitis? Allergol et Immunopathol 2011, in press.

96 Abu El-Asrar AM, Struyf S, Al-Mosallam AA, et al. Expression of chemokine receptors in vernal keratoconjunctivitis. Br J Ophthalmol 2001:85:1357-61.

97 Lambiase A, Bonini S, Rasi G, et al. Montelukast, a leukotriene receptor antagonist, in vernal keratoconjunctivitis associated with asthma. Arch Ophthalmol 2003;121:615-20.

98 Abelson M, Butrus S, Weston J. Aspirin therapy in vernal keratoconjunctivitis. Am J Ophthalmol 1983;95:502-5.

99 Gokhale N, Samant R, Sharma V. Oral cyclosporine therapy for refractory severe vernal keratoconjunctivitis. Indian J Ophthalmol 2012;60:220-3.

100 Meyer $E$, Kraus E, Zonis S. Efficacy of antiprostaglandin therapy in vernal keratoconjunctivitis. Br J Ophthalmol 1987;71:497-99.

101 Singh S, Pal V, Dhull CS. Supratarsal injection of corticosteroids in the treatment of refractory vernal keratoconjunctivitis. Indian J Ophthalmol 2001:49:241-45.

102 Egrilmez S, Sahin S, Yagci A. The effect of vernal keratoconjunctivitis on clinical outcomes of penetrating keratoplasty for keratoconus. Can J Ophthalmol 2004;39:772-77.

103 Sangwan VS, Murthy SI, Vemuganti GK, et al. Cultivated corneal epithelial transplantation for severe ocular surface disease in vernal keratoconjunctivitis. Cornea 2005;24:426-30.

104 Rouher N, Pilon F, Dalens $\mathrm{H}$, et al. Implantation of preserved human amniotic membrane for the treatment of shield ulcers and persistent corneal epithelial defects in chronic allergic keratoconjunctivitis. J Fr Ophtalmol 2004;27:1091-97.

105 Basu S, Taneja M, Sangwan VS. Boston type 1 keratoprosthesis for severe blinding vernal keratoconjunctivitis and Mooren's ulcer. Int Ophthalmol 2011;31:219-22.

106 Tanaka M, Dogru M, Takano Y, et al. Quantitative evaluation of the early changes in ocular surface inflammation following MMC-aided papillary resection in severe allergic patients with corneal complications. Cornea 2006;25:281-85.

107 BenEzra D, Pe'er J, Brodsky M, et al. Cyclosporine eyedrops for the treatment of severe vernal keratoconjunctivitis. Am J Ophthalmol 1986;101:278-82. 


\section{Vernal keratoconjunctivitis: an update}

Stefan De Smedt, Gerhild Wildner and Philippe Kestelyn

Br J Ophthalmol 2013 97: 9-14 originally published online October 4, 2012

doi: 10.1136/bjophthalmol-2011-301376

Updated information and services can be found at:

http://bjo.bmj.com/content/97/1/9

These include:

References This article cites 102 articles, 17 of which you can access for free at: http://bjo.bmj.com/content/97/1/9\#BIBL

Email alerting Receive free email alerts when new articles cite this article. Sign up in the service box at the top right corner of the online article.

Topic Articles on similar topics can be found in the following collections

Collections

Conjunctiva (203)

Cornea (467)

Ocular surface (557)

Epidemiology (928)

\section{Notes}

To request permissions go to:

http://group.bmj.com/group/rights-licensing/permissions

To order reprints go to:

http://journals.bmj.com/cgi/reprintform

To subscribe to BMJ go to:

http://group.bmj.com/subscribe/ 